\title{
RANCANG BANGUN QR CODE SEBAGAI MEDIA OPTIMALISASI PELAYANAN UNTUK PENDAFTARAN PENERIMAAN MAHASISWA BARU
}

\author{
Ikbal Nidauddin ${ }^{1}$, Khaidir Fahram ${ }^{2}$ \\ ${ }^{1}$ Program Studi Manajemen Informatika Politeknik Piksi Input Serang \\ ${ }^{2}$ Program Studi Teknik Informatika STTIKOM Insan Unggul \\ ${ }^{1}$ Jl.Raya Serang Cilegon Km.8 Kramatwatu Serang Banten \\ ${ }^{2}$ Jl. Jendral Sudirman No.146 Kavling 25, Komplek Istana Cilegon, Kecamatan Cilegon \\ ${ }^{1}$ ikbalnidauddin@ piksiinputserang.ac.id \\ ${ }^{2}$ khaidir@insan-unggul.ac.id
}

\begin{abstract}
Abstrak - Pendaftaran Mahasiswa Baru merupakan proses administrasi yang dilakukan di Perguruan Tinggi, Proses Pendaftaran calon mahasiswa baru di Politeknik Piksi Input Serang dilakukan dengan cara mengisi Formulir oleh calon mahasiswa, kemudian data tersebut diinputkan kembali oleh panitia menggunakan komputer secara offline. Dalam melakukan pelayanan Offline masih banyak terdapat waktu yang kurang maksimal dan belum optimal. Optimalisasi pelayanan untuk pendaftaran penerimaan mahasiswa baru menggunakan web sudah banyak diterapkan dibeberapa Perguruan Tinggi di Indonesia. Namun calon mahasiswa baru masih banyak yang merasa kesulitan dengan sisten tersebut Karena masih sederhana. Kemudian calon mahasiswa tidak semua mengerti dalam mengoptimalkan system informasi berbasis berbasis web. Oleh karena itu penulis memberikan solusi dengan membangun $Q R$ Code sebagai media Optimalisasi pelayanan untuk pendaftaran penerimaan mahasiswa baru.
\end{abstract}

Kata kunci : Pendaftaran, Optimalisasi Pelayanan, QR Code, Pendaftaran, Penerimaan, Mahasiswa Baru.

\section{Pendahuluan}

Pendidikan Tinggi merupakan jenjang pendidikan setelah pendidikan menengah yang mencakup program pendidikan diploma, sarjana, magister, spesialis, dan doktor yang diselenggarakan oleh pendidikan tinggi. Pendidikan tinggi diselenggarakan dengan sistem terbuka ${ }^{1}{ }^{1}$.

SMA merupakan jenjang pendidikan menengah yang mengutamakan penyiapan siswa untuk melanjutkan pendidikan yang lebih tinggi dengan pengkhususan $\left[{ }^{2}\right]$.

Pelayanan (customer service) secara umum adalah setiap kegiatan yang diperuntukkan atau ditujukan untuk memberikan kepuasan kepada pelanggan, melalui pelayanan ini keinginan dan kebutuhan pelanggan dapat terpenuhi $\left[{ }^{3}\right]$. Rencana pembangunan pendidikan jangka panjang 2020- 2045 telah dijabarkan ke dalam empat tema pembangunan pendidikan, yaitu peningkatan kapasitas dan modernisasi (2020- 2024), penguatan pelayanan (2025- 2029), penguatan daya saing regional (2030-2034) dan penguatan daya saing internasional (20352039). Rencana pembangunan ini berimplikasi kepada stakeholders pendidikan, sehingga dalam pembangunan pendidikan nasional bertujuan untuk meningkatkan kualitas pelayanan pendidikan yang berdampak pada peningkatan kepuasan akademik setiap pengguna jasa pendidikan, utamanya adalah peserta didik. $\left[{ }^{5}\right]$.

Setiap mahasiswa menghendaki kepuasan maksimal dari setiap layanan yang terdapat di lingkungan kampus. Tentunya dengan kepuasan maksimal yang didapat mahasiswa akan dapat meningkatkan kesejahteraan bagi yang bersangkutan. Kepuasan adalah tingkat perasaan.

Sedangkan definisi yang lain menyatakan bahwa pelayanan atau service adalah setiap kegiatan atau manfaat yang diberikan suatu pihak kepada pihak lainnya yang pada dasarnya tidak berwujud dan tidak pula berakibat pemilikan sesuatu dan seseorang setelah membandingkan kinerja yang 
berarti terbaik, tertinggi, paling menguntungkan, menjadikan paling baik, menjadikan paling tinggi, pengoptimalan proses, cara, perbuatan mengoptimalkan (menjadikan paling baik, paling tinggi, dan sebagainya) sehingga optimalisasi adalah suatu tindakan, proses, atau metodologi untuk membuat sesuatu (sebagai sebuah desain, sistem, atau keputusan) menjadi lebih/sepenuhnya sempurna, fungsional, atau lebih efektif [7].

Optimalisasi Pelayanan untuk Pendaftaran Mahasiswa Baru dilingkungan Politeknik Piksi Input Serang masih bersifat manual yang dilakukan dengan cara menulis didalam lembar formulir pendaftaran sehingga membutuhkan antrian yang lama.

Panitia Penerimaan Mahasiswa Baru pada Perguruan Tinggi Politeknik Piksi Input Serang ini membutuhkan Optimalisasi Pelayanan untuk bisa memberikan informasi yang akurat untuk pendaftaran mahasiswa baru.

Maka Penulis memberikan solusi dengan Rancang Bangun QR Code sebagai media optimalisasi pelayanan untuk pendaftaran penerimaan mahasiswa baru .

\section{METODOLOGI PENELITIAN}

Metodologi yang digunakan dalam penulisan ini adalah metode perancangan system yang digunakan dalam membangun rancang bangun system.

\subsection{Teknik Pengumpulan Data}

A. Observasi

Pengumpulan data dengan pengamatan langsung ke lokasi penelitian yaitu Politeknik Piksi Input Serang, guna mendapatkan informasi secara langsung

B. Wawancara

Melakukan wawancara langsung dengan panitia PMB untuk memperoleh data tentang siswa meningkatkan kesejahteraan bagi yang bersangkutan. Kepuasan adalah tingkat perasaan.

Menurut Kamus Besar Bahasa Indonesia Optimalisasi adalah berasal dari kata dasar optimal.

\section{A. Analisa Kebutuhan Sistem}

Pada tahapan ini perlu melakukan analisa dengan melakukan observasi dan dari hasil observasi diperoleh kebutuhan-kebutuhan yang diperlukan dalam penelitian. Data yang dibutuhkan seperti data calon mahasiswa baru, pembuatan laporan hasil penerimaan mahasiswa baru.

\section{B. Desain}

Proses ini focus pada desain rancang bangun optimalisasi pelayanan penerimaan mahasiswa baru. Dimulai dari tahap Unified Modelling Language (UML).adapun diagram yang digunakan yaitu : Use Case Diagram, Acitivty Diagram, Sequence Diagram. Dilanjutkan dengan merancang basis data (database) menggunakan ERD (Entity Relationship Diagram)

$$
\text { C. Code Generation }
$$

perangkat lunak. Pada tahap ini penerjemah data atau pemecah masalah yang sudah dirancang kedalam bahasa pemrograman.

$$
\text { D. Testing }
$$

Pengujian focus pada perangkat lunak secara dari seg lojik dan fungsional dan memastikan bahwa semua bagian sudah diuji. Hal ini dilakukan meminimalisir kesalahan (error) dan memastikan keluaran yang dihasilkan dengan sesuai yang diinginnkan.

E. Support

Setelah aplikasi dibuat, dibutuhkan instalasi pada setiap clien.

\section{A. Tahapan Analisa}

Pelayanan mahasiswa baru pada Politeknik Piksi Input Serang

1. Halaman Depan :

A. Disajikan halaman barcode

2. Halaman Informasi Pendaftaran

A. Halaman ini menyajikan bagaimana cara mendaftar melalui online, dokumen yang harus dipersiapkan untuk bisa diterima dalam perguruan tinggi Politeknik Piksi Input Serang

3. Halaman formulir pendaftaran

A. Halaman ini berisi data yang dibutuhkan oleh sistem yang diisi sesuai dengan keadaan yang ada.

\section{Halaman kelengkapan berkas}

Halaman ini diisi oleh calon mahasiswa baru untuk melengkapi data sesuai kebutuhan dan upload file.

C. Studi Pustaka

Melakukan dengan cara membaca, mengutip dan mencatat sumber pada bahan-bahan pustaka yang mendukungn dan berkaitan dengan pelayanan PBM. Selanjutnya dengan cara mempelajari dan memahami sistem yang berhubungan dengan cara mempelajari dan memahami sistem yang berhubungan dengan masalah yang akan dibahas dalam penelitian.

2. Metode pengembangan Sistem

Model waterfall adalah suatu metodologi pengembangan perangkat lunak yang mengusulkan pendekatan kepada perangkat lunak sistematik dan sekuensial yang mulai pada tingkat kemajuan sistem seluruh analisis, desain kode, pengujian dan pemeliharaan.

\section{HASIL DAN PEMBAHASAN}

\subsection{Analisa kebutuhan software}

Dalam rancang bangun optimalisasi pelayanan penerimaan mahasiswa baru maka peneliti melakukan kebutuhan software untuk dapat mengetahui proses yang terjadi dalam suatu sistem. Adapun analisa kebutuhan software di Politeknik Piksi Input Serang sebagai berikut : 


\section{A. Tahapan Analisa}

Pelayanan mahasiswa baru pada Politeknik Piksi Input Serang

1. Halaman Depan :

Disajikan halaman barcode

2. Halaman Informasi Pendaftaran

Halaman ini menyajikan bagaimana cara mendaftar melalui online, dokumen yang harus dipersiapkan untuk bisa diterima dalam perguruan tinggi Politeknik Piksi Input Serang

3. Halaman formulir pendaftaran

Halaman ini berisi data yang dibutuhkan oleh sistem yang diisi sesuai dengan keadaan yang ada.

4. Halaman kelengkapan berkas

Halaman ini diisi oleh calon mahasiswa baru untuk melengkapi data sesuai kebutuhan dan upload file

\section{Studi Pustaka}

Melakukan dengan cara membaca, mengutip dan mencatat sumber pada bahan-bahan pustaka yang mendukungn dan berkaitan dengan pelayanan PBM. Selanjutnya dengan cara mempelajari dan memahami sistem yang berhubungan dengan cara mempelajari dan memahami sistem yang berhubungan dengan masalah yang akan dibahas dalam penelitian.

\section{B. Usecase Diagram}

Usecase Diagram digunakan untuk mendeskripsikan tipikal interaksi antar pengguna dengan sebuah sistem melalui sebuah cerita bagaimana sistem tersebut digunakan.

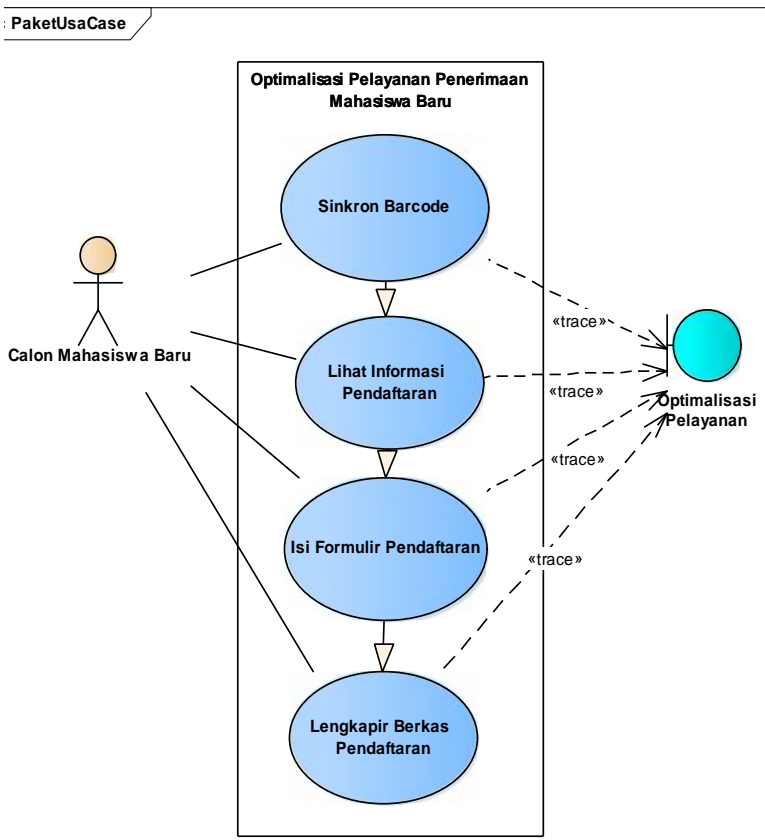

Sumber : Hasil Penelitian (2019)

Gambar 1. Rancangan Usecase Diagram

\section{Activity Diagram}

Activity Diagram menggambarkan berbagai alur aktivitas dalam sistem yang sedang dirancang, bagaimana masing-masing alur berawal, decision yang mungkin terjadi dan bagaimana berakhir.

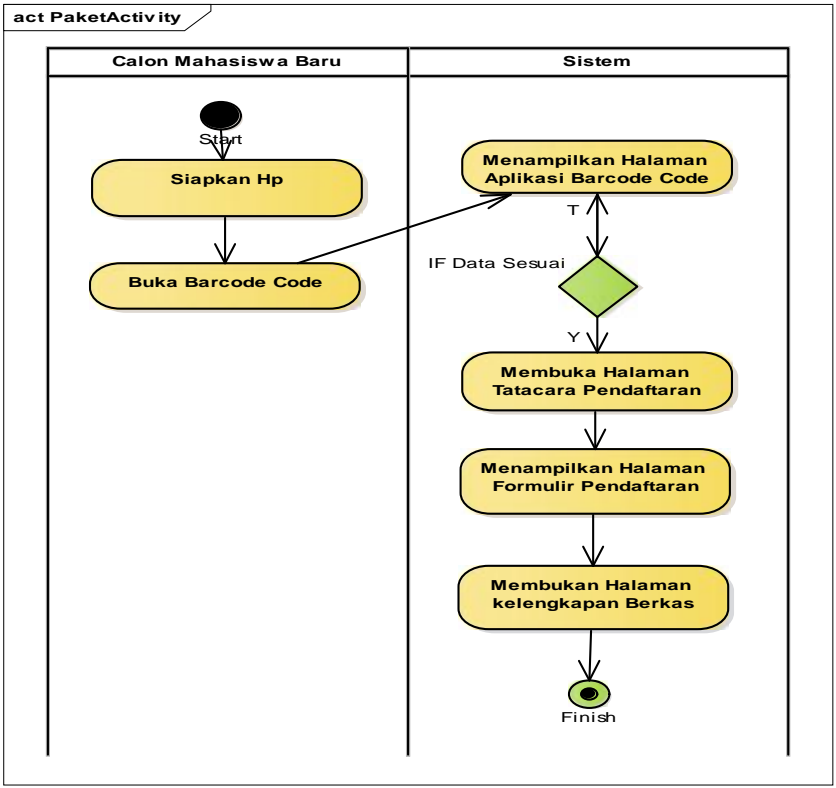

Sumber : Hasil Penelitian (2019)

Gambar 2 . Rancangan Activity Diagram

D. Sequence Diagram

Sequence Diagram digunakan untuk menggambarkan perilaku pada sebuah scenario. Kegunaannya untuk menunjukkan rangkaian pesan yang dikirim antara object juga interaksi antara object, sesuatu yang terjadi pada titik tertentu dalam eksekusi system.

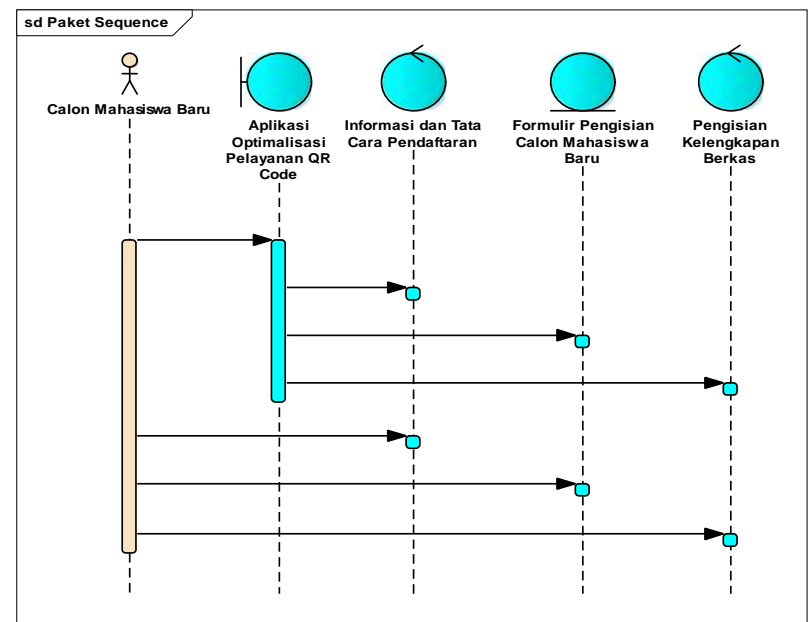


Sumber : Hasil Penelitian (2019)

Gambar 3 . Rancangan Sequence Diagram

\subsection{Desain}

Pada tahapan ini akan menjelaskan tentang desain database, desain software architecture dan desain interface dari aplikasi yang sedang dibuat.

1. Database

A. Entity Relationship Diagram

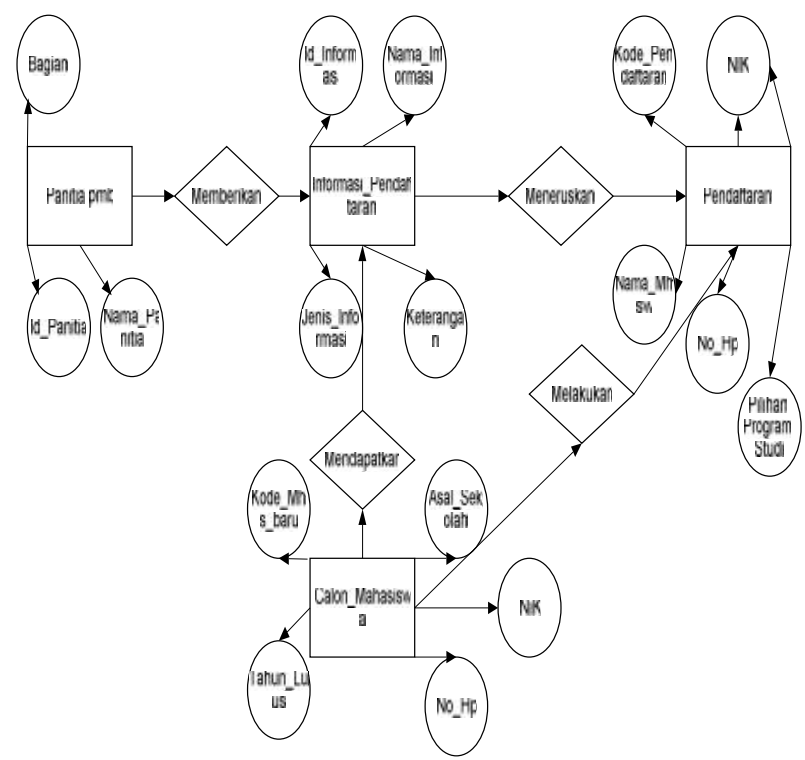

Sumber : Hasil Penelitian (2019)

Gambar 4 . Rancangan Entity Relationship Diagram

\subsection{Implementasi}

Pengembangan dari perancangan yang telah dibuat untuk diterjemahkan menjadi kumpulan kode dan fungsi menggunakan Bahasa.

\section{Tampilan Halaman Depan}

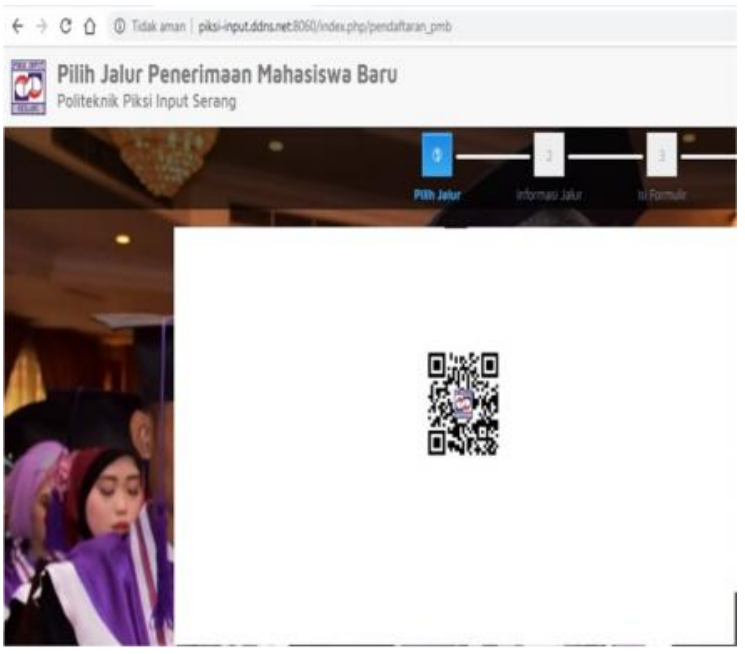

Sumber : Hasil Penelitian (2020)

Gambar 5 . Halaman Optimalisasi Barcode

2. Halaman Pendaftaran

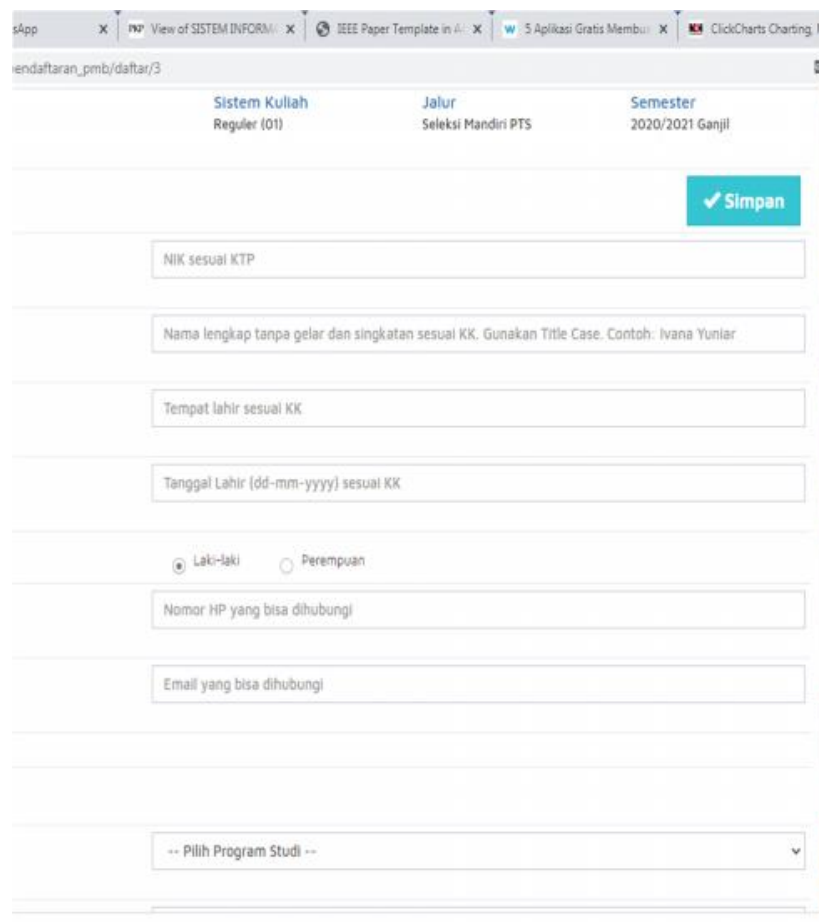

\section{0 面}

Sumber : Hasil Penelitian (2019)

Gambar 6 . Halaman Pendaftaran

3. Halaman Kelengkapan Berkas

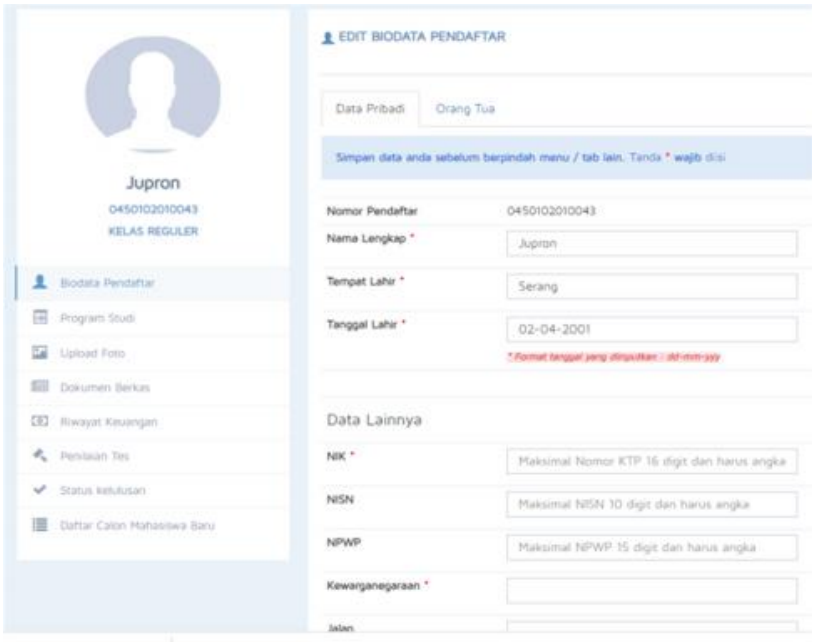


Sumber : Hasil Penelitian (2019)

Gambar 7. Halaman Kelengkapan Berkas

\section{Halaman Tampilan Laporan}

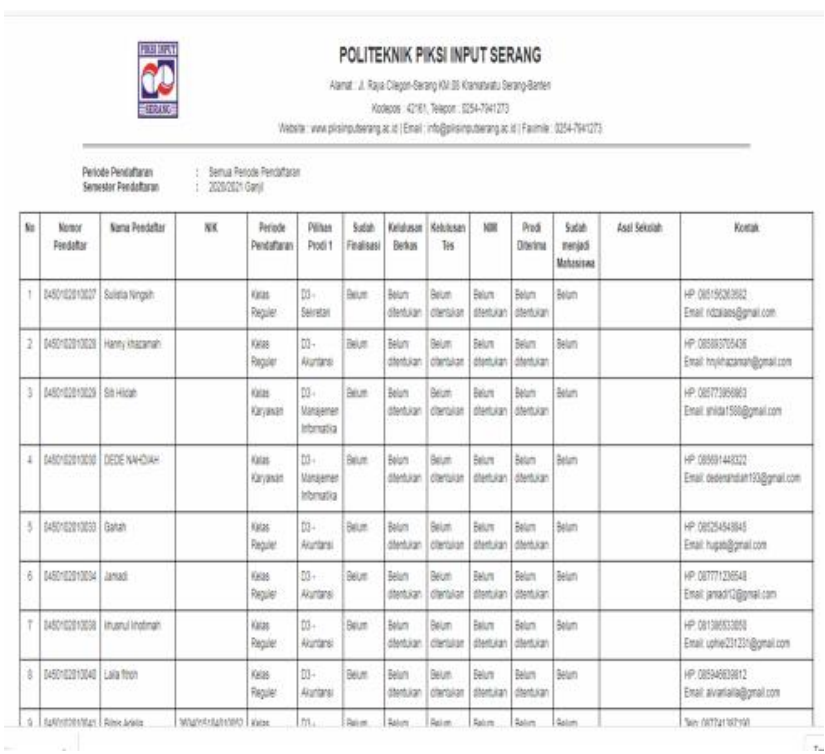

Sumber : Hasil Penelitian (2019)

Gambar 8. Halaman Tampilan Laporan

\section{KESIMPULAN}

Berdasarkan hasil Rancang Bangun Qr Code Sebagai Media Optimalisasi Pelayanan Untuk Pendaftaran Penerimaan Mahasiswa Baru, maka simpulanya adalah :

1. Media Optimalisasi QR Code sebagai pelayanan pendaftaran penerimaan mahasiswa baru dapat membantu calon mahasiswa baru untuk bisa mendapatkan informasi dan mendaftar di Politeknik Piksi Input Serang

2. Dengan diterapkannya aplikasi ini diharapkan mempermudah calon mahasiswa untuk mendapatkan informasi dan mendaftar di Politeknik Piksi Input Serang.

3. Hasil Rancangan bisa digunakan oleh semua kalangan yang mempunyai gadget atau Handphone yang mendukung QR Code

\section{REFERENSI}

[1] Kasmir, (2010). Manajemen Perbankan, (Jakarta, PT Raja Grafindo Persada, )

[2] Kotler, Philip. (2003). Marketing Management, New Jersey: Mico International Inc

[3] Munir (2006). Manajemen Pelayanan Umum, (Jakarta: Bumi Aksara,),

[4] Solekhul Amin (2017). Strategi Peningkatan Kualitas Pelayanan Akademik pada Perguruan Tinggi, Jurnal Madaniyah, Volume 7 Nomor 2 Edisi Agustus

[5] Tim Penyusun, Kamus Besar Bahasa Indonesia, Jakarta : Balai Pustaka, 1990) 